\title{
TGF-beta1 on osteoimmunology and the bone component cells
}

\author{
Shimpei Kasagi and Wanjun Chen ${ }^{*}$
}

\begin{abstract}
TGF- $\beta 1$ is an immunoregulatory cytokine that regulates immune cell proliferation, survival, differentiation, and migration. Compelling evidence has demonstrated a strong association between the immune and skeletal systems (so called Osteoimmunology), such as the critical role of TGF- $\beta 1$ in the development and maintenance of the skeletal tissue. This review provides an overview of the mechanisms in which TGF- $\beta 1$ interacts with bone component cells, such as osteoblasts, osteoclasts, chondrocytes, mesenchymal stem cells, and hematopoietic stem cells, in concert with other cytokines and hormones.
\end{abstract}

\section{Introduction}

Bone is a rigid organ that constitutes part of the endoskeleton of vertebrates. It serves multiple functions; providing mechanical support for joints and tendons, protecting soft tissue or various organs from mechanical stress or trauma, storing minerals, generating hematopoietic cells, and producing hormones. These many functions are regulated by several soluble factors. Interestingly, accumulated evidence indicates that transforming growth factor beta 1 (TGF- $\beta 1$ ) plays a critical role in bone formation, mineral storage, and hematopoietic cell generation. In addition, recent progress in the study of the cross-talk between the skeletal system and the immune system (termed osteoimmunology) has revealed shared components and mechanisms between the two systems [1]. This review highlights recent findings focusing on the role of TGF- $\beta 1$ in bone metabolism and osteoimmunology.

\section{Function of TGF- $\beta 1$ in the immune system}

TGF- $\beta 1$ is a one of the most potent regulatory cytokines with diverse effects on hematopoietic cells. In the immune system, TGF- $\beta 1$ induces and maintains immune tolerance by regulation of lymphocyte proliferation, differentiation, and survival. Disruption of TGF- $\beta 1$ results in a dysregulated immune system [2], leading to inappropriate immune cell activation, inflammation, cancer (Leukemia and malignant lymphoma etc) and autoimmune diseases [3]. In fact, TGF- $\beta 1$-deficient mice (TGF- $\beta 1$ ko) die within 2-3 weeks

\footnotetext{
* Correspondence: wchen@dir.nidcr.nih.gov

Mucosal Immunology Section, NIDCR, NIH, Bethesda, MD, USA
}

after birth due to lymphocyte and monocyte infiltration of multiple vital organs $[3,4]$. CD $4^{+}$Foxp $3^{+} \mathrm{T}$ cells that predominantly produce anti-inflammatory cytokines (TGF- $\beta$, IL-10), but not inflammatory cytokines (IFN- $\gamma$, TNF- $\alpha$, and IL-17) are known as regulatory T cells (Tregs). They inhibit the action of other effector T cells through soluble factors (TGF- $\beta$ or IL-10) or cell-to-cell contact [5]. It is well known that TGF- $\beta$ suppresses inflammatory cytokine production by effector $\mathrm{T}$ cells, and additionally, it drives the differentiation of naïve $\mathrm{T}$ cells to $\mathrm{CD} 4{ }^{+} \mathrm{CD} 25^{+} \mathrm{Foxp}^{+}$Tregs [6]. Moreover, TGF- $\beta$ controls the initiation and resolution of inflammatory responses through the regulation of chemotaxis, activation, and survival of lymphocytes [2], natural killer cells [7], dendritic cells [8], macrophages [9], mast cells [10], and granulocytes [11]. These findings indicate that TGF- $\beta$ plays critical roles in the regulation of immune responses.

\section{Bone component cells in bone remodeling}

Bone remodeling is a lifelong process where mature bone tissue is removed from the skeleton (a process called bone resorption) and new bone tissue is generated (a process called bone formation). An imbalance between bone resorption and bone formation results in many metabolic bone diseases, such as osteoporosis and Camurati-Engelmann disease [12,13]. The cells responsible for bone formation are known as osteoblasts which secrete new bone, and those responsible for bone resorption are known as osteoclasts, which break bone down. Osteoblasts arise from mesenchymal stem cells (MSCs) located in bone marrow, and Osteoclasts are generated from hematopoietic

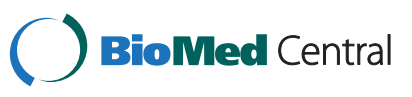


stem cells (HSCs). TGF- $\beta 1$ controls both osteoblast and osteoclast differentiation, and therefore balances bone formation and resorption [14] (Figure 1).

The TGF- $\beta$ family contains three closely related mammalian isoforms-TGF- $\beta 1,-\beta 2$, and $-\beta 3$, yet TGF- $\beta 1$ constitutes the largest sources of TGF- $\beta$ in bone [15]. In mice, TGF- $\beta 1$ protein is detected in bone marrow cells, chondrocytes, and the cartilaginous matrix [16]. As discussed in the next chapter, TGF- $\beta 1$ regulates bone formation through enhancement of osteoblast proliferation [17], differentiation[18], and chemotactic attraction[19], and also extracellular matrix and proteoglycan synthesis of chondrocyte precursor cells [20]. We will discuss how TGF- $\beta 1$ maintains bone homeostasis through regulating bone-forming cells, individually.

\section{TGF- $\beta 1$ and osteoblasts}

Osteoblasts are mononucleated cells that are responsible for bone formation. They arise from osteoblastic precursors located in the deeper layer of periosteum and the bone marrow, and produce a matrix of osteoid, which is composed mainly of type I collagen [21]. TGF- $\beta 1$ has a variety of widely recognized roles in bone formation. For example, TGF- $\beta 1$ enhances osteoblast proliferation [17], blocks apoptosis of osteoblasts [18], and also recruits osteoblastic precursors or matrix-producing osteoblasts to the site through chemotactic attraction [19]. In addition, TGF- $\beta 1$ enhances the production of extracellular bone matrix protein by osteoblasts in the early stages of osteoblast differentiation [22]. On the other hand,
TGF- $\beta 1$ inhibits the later phase of osteoblast proliferation and mineralization [23]. It has been previously reported that both TGF- $\beta$ receptor I and receptor II expression in murine, rat, and human osteoblasts was decreased during osteoblast differentiation, which may imply that osteoblasts are less sensitive to TGF- $\beta 1$ in the late phase of their differentiation [24]. The later stages are positively regulated by bone matrix proteins (BMP), which are members of the TGF- $\beta$ superfamily [25]. Therefore, TGF- $\beta 1$ cooperates with BMP to regulate the differentiation of osteoblasts.

Runt-related transcription factor 2 (Runx2), also known as core-binding factor subunitalpha-1 (Cbfa1), is a DNA-binding transcription factor important in specifying osteogenic lineage [26]. Runx2 is the master transcription factor in bone formation, and several reports indicated that it is regulated by TGF- $\beta 1$ and BMP-2. In the initial phase of osteoblastic differentiation (differentiation of MSCs to osteoblast progenitor cells), Runx2 inhibited differentiation of MSCs to types of cells other than osteoblasts, which required coordinated action between Runx2 and BMP2-induced Smad5 [27]. In the second phase of their differentiation (from osteoblast progenitor cells to osteoblasts), TGF- $\beta 1$ induced the expression of Runx2, which cross-talks with beta-catenin signaling to promote differentiation [28]. However, in the final differentiation stages of osteoblasts (mature osterblasts), TGF- $\beta 1$ opposes BMP-2 actions [27]. Smad3, activated by TGF- $\beta 1$, physically interacts with Runx2 at Runx2-responsive elements, and suppresses

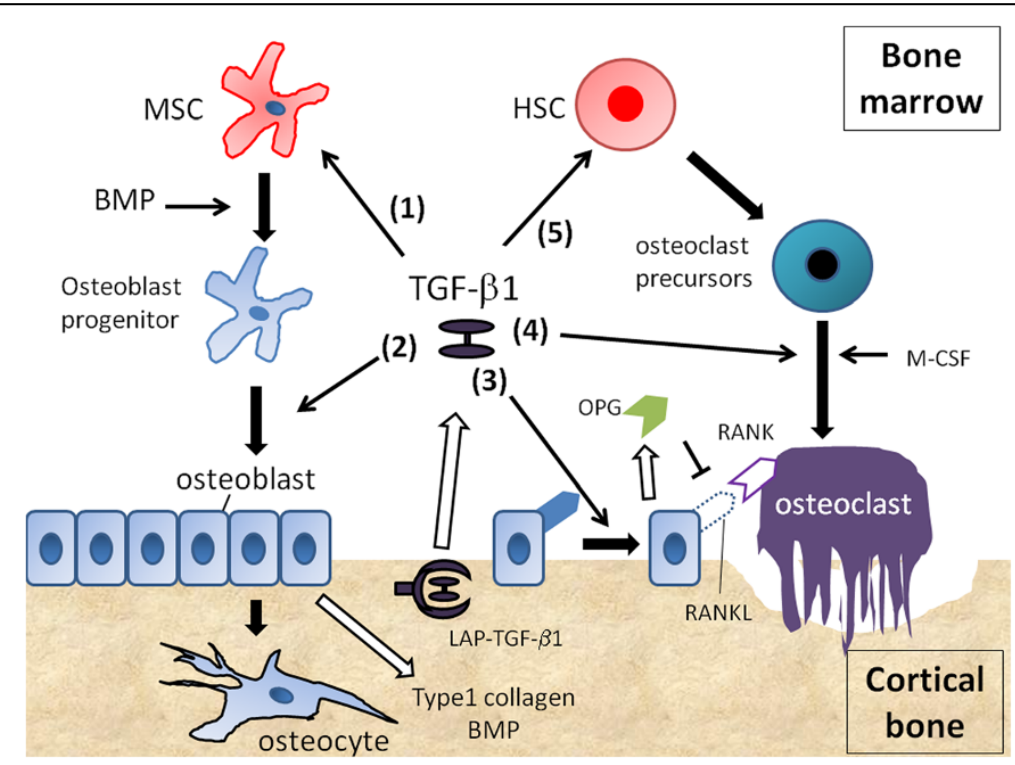

Figure 1 Five major role of TGF- $\beta 1$ in osteoimmunity are shown. (1) TGF- $\beta 1$ stimulates the proliferation of MSCs, and promotes their differentiation into chondrocytes. (2) TGF- $\beta 1$ promotes osteoblast progenitor's differentiation into osteoblast. (3) High concentration of TGF- $\beta 1$ enhances osteoblast proliferation, and downregulates the expression of RANKL of osteoblast. (4) Low concentration of TGF- $\beta 1$ promoted osteoclast maturation. (5) TGF- $\beta$ keeps hematopoietic stem cells (HSC) in hibernation state. 
the expression of Runx2. Runx 2 prevents the differentiation of mature osteoblasts into osteocytes, and maintains them in a resting state. Thus, TGF- $\beta 1$ may promote osteocyte development by downregulating Runx 2 in mature osteoblasts [18]. These findings indicate that TGF- $\beta 1$ finely tunes osteoblast differentiation.

\section{TGF- $\beta 1$ and osteoclasts}

The role of TGF- $\beta 1$ in osteoclastogenesis and bone resorption is very complex and controversial. It is clear that TGF- $\beta 1$ mediates osteoclasts functions, such as their maturation [29], apoptosis [30], and the recruitment of osteoclast precursors from spleen or bone marrow [31]. Several reports indicated that TGF- $\beta 1$ had a biphasic effect on the osteoclast maturation. TGF- $\beta 1$ induces osteoclastogenesis of hematopoietic precursor and other osteoclastic precursors when it is added into the culture with receptor activator of nuclear factor kappa B ligand (RANKL) and macrophage colony stimulating factor (M-CSF) [32]. TGF- $\beta 1$ triggers the expression of nuclear kappa $\mathrm{B}(\mathrm{NF}-\mathrm{k} \mathrm{B})$ and receptor activator of nuclear factor kappa B (RANK) in osteoclast precursors, and RANKL-RANK interaction is important for prolonged survival and augmented differentiation of osteoclast precursors into osteoclasts [32]. On the other hand, when osteoclast precursors were cultured with osteoblasts, it seemed that osteoclast activation was attenuated especially when they were stimulated with high concentrations of TGF- $\beta 1$ (1-10 ng/ml), while low concentrations of TGF- $\beta 1(1-10 \mathrm{pg} / \mathrm{ml})$ promoted osteoclast maturation [33]. High concentrations of TGF- $\beta 1$ upregulated the expression and secretion of osteoproteogerin (OPG) and down regulated that of RANKL by osteoblasts [34]. OPG is a decoy receptor for RANKL, and inhibits the RANKL-RANK interaction by binding to RANKL on osteoblasts [35]. As a result, the differentiation of osteoclast precursors into mature osteoclasts mediated by RANKL-RANK is inhibited by OPG released from osteoblasts.

\section{RANKL-RANK-OPG axis and osteoimmunology}

The RANKL-RANK-OPG axis is an important signaling system functioning both in bone and immune cell communication. RANKL expressed on $\mathrm{T}$ cells or soluble forms of RANKL are able to induce matured osteoclasts. RANK is also expressed on dendritic cells, and RANKL activates dendritic cells by binding to RANK. RANKL/ RANK signaling inhibited apoptosis of dendritic cells, resulting in an increase in dendritic cell-mediated $\mathrm{T}$ cell proliferation in a mixed leukocyte reaction [36]. OPG is expressed on monocytes, T cells and B cells [37]. Interestingly, cytokines stimulating the osteoclastogenesis, such as IL-1 $\beta$, IL-6, IL-17, and TNF- $\alpha$ increased the expression of RANKL with decrease of OPG expression in osteoblasts [37]. These findings suggest that RANKLRANK-OPG axis may regulates immune responses. More recently, RANKL-RANK-OPG axis has been reported to be involved in the pathogenesis of degenerative bone diseases, such as rheumatoid arthritis and psoriatic arthritis, post menopausal osteoporosis, and bone metastasis $[37,38]$. Novel strategic treatments are emerging that are based on an understanding of the functional status of the OPG/RANK/RANKL triad.

\section{TGF- $\beta 1$ and mesenchymal stem cells}

MSCs are muitipotent progenitor cells that have the ability to differentiate into mesenchymal lineages, including osteoblasts (bone), chondrocytes (cartilage) and adipocytes [39]. The differentiation, and function of MSCs can be regulated by TGF- $\beta 1$. For example, TGF- $\beta 1$ stimulates the proliferation of MSCs and promotes their differentiation into chondrocytes [40]. TGF- $\beta 1$ promotes chondrogenesis as well as the early phase of osteogenesis, however in the absence of BMPs, TGF- $\beta 1$ is unable to promote differentiation of MSCs into osteoblasts as described previously [27].

MSCs have potent immunosuppressive effects through cell-to-cell contact and by secreting soluble factors. They have a clear potential for clinical application for the repair of damaged tissue [41] and in the therapy of autoimmune diseases and chronic inflammation [42]. Soluble factors secreted by MSCs include indoleamine 2,3-dioxygenase (IDO), prostaglandin E2 (PGE2), and TGF- $\beta$ which all plays a major role in MSC-mediated suppression of $\mathrm{T}$ cell proliferation induced by mitogens or alloantigens $[43,44]$. IDO metabolizes tryptophan to kynurenine, which causes depletion of local tryptophan and reduction of lymphocyte proliferation $[45,46]$. PGE2 is a powerful mediator that inhibits $\mathrm{T}$ cell mitogenesis and IL-2 production [47]. Park et al. recently reported that TGF- $\beta 1$-transduced MSCs, but not control MSCs, suppressed the development of type II collagen-induced arthritis (CIA). In vivo treatment with TGF- $\beta$-transduced MSCs reduced bone erosion and cartilage destruction by suppressing type II collagen-specific $\mathrm{T}$ cell proliferation, by down-regulating proinflammatory cytokine production (IL-6, TNF- $\alpha$, and IL-17), and by increasing the number of type II collagen-specific $\mathrm{CD} 4^{+}$Foxp $3^{+}$Tregs in the spleen [48]. These findings suggested that TGF- $\beta$ produced by MSCs in vivo could play a key role in peripheral tolerance and bone repair.

\section{TGF- $\beta$ And hematopoietic stem cells in bone marrow}

Hematopoiesis is the formation of blood cellular components (red blood cells, white blood cells, and platelets), and critical to maintain their number in the peripheral circulation. Hematopoietic stem cells (HSCs) reside and self-renew in the bone marrow (BM) niche, and have the 
unique ability to give rise to all of the different mature blood cell types. The term 'BM niche' was introduced in the 1980s to define the spatial and temporal structure harboring stem cells [49]. Many different cell types have been characterized as contributing to the formation of HSC BM niches, such as osteoblasts, endothelial cells, MSCs, and reticular cells [50]. In the BM niche, most of the HSCs are kept in hibernation or undifferentiated states and few cells are recruited into the cell cycle at long intervals, on average every 1 to 2 months [51]. Tight regulation of HSCs' proliferation and differentiation is vital to retain the high quality of HSCs. This process is also critical to avoid autoimmune diseases or hematologic malignancy triggered by abnormal HSCs released from BM to periphery. HSCs outside the niche do not self-renew and commence the process of differentiation to produce mature blood cells [51], indicating that the presence of $\mathrm{BM}$ niche is critical for HSCs homeostasis.

Recently, TGF- $\beta$ has been reported to contribute to the formation of HSC niches. Yamazaki et al. reported that TGF- $\beta$ produced by glial cells (one of the components of BM niche) was critical for the maintenance of BM niche [52]. They demonstrated that TGF- $\beta$ type II receptor-deficient HSCs showed impaired long-term self-renewal activity. They also demonstrated that latent TGF- $\beta$, produced by a variety of BM cells, was broadly distributed within BM, while, active TGF- $\beta$ was exclusively detectable in glial cells that lay in parallel with blood vessels. Since two distinct areas (perivascular area and endosteal area) have been characterized as HSCs niches [50], their finding suggested that active TGF- $\beta$ released by glial cells has a critical role in the perivascular BM niche. MSCs and osteoblasts, which are the components of the endosteal niche, recruit HSCs and maintain their survival by producing HSCs promoting factors [50]. However, it remains unknown if TGF- $\beta$ produced by MSCs is critical for the maintenance of BM niche. Further investigation is required to establish this new concept.

\section{TGF- $\beta$ and T cells in osteogenesis}

The role of TGF- $\beta$ signaling in T cells and the effect of this upon osteogenesis was previously investigated by Gao et al [53]. They reported that disruption of $\mathrm{T}$ cell specific TGF- $\beta$ signaling led to bone loss. T cells purified from CD4 dominant negative TGF- $\beta$ RII mice produced more TNF- $\alpha$ and RANKL than wild type mice. These factors, in concert, stimulated osteoclasts formation and activity, which resulted in impaired skeletal maturation and bone loss in estrogen repleted mice (osteoporosis model mice). In vivo treatment with a TGF- $\beta 1$ expression vector restored bone loss through deactivating effector $\mathrm{T}$ cell function, suggesting that
TGF- $\beta 1$ signaling in T cells could modify bone metabolism. In addition to the effects of TGF- $\beta 1$, TGF- $\beta 2$ also influences $\mathrm{T}$ cells effctor function which has implications for osteogenesis. TGF- $\beta 2$ inhibits $\mathrm{T}$ cell activation through TGF- $\beta R 2$, suggesting that the absence of TGF- $\beta 2$-mediated signaling may be a candidate of dysregulated production of TNF- $\alpha$ and RANKL in CD4 dominant negative TGF- $\beta$ RII mice. Notably, it has been reported that TGF- $\beta 2$ stimulates synthesis of TGF- $\beta 1$ in chondrocytes and osteoblasts within newly generated bone and cartilage, indicating a positive autoregulation of TGF- $\beta$ [54]. Together, these results suggest that TGF- $\beta 2$ signaling play a regulatory role in T cell activation and bone metabolism.

TNF- $\alpha$ has been previously reported to promote osteoblast apoptosis [55] and osteoclasts genesis from bone marrow macrophages [56]. TGF- $\beta 1$ attenuates TNF- $\alpha-$ induced osteoblasts apoptosis and bone resorption [57]. Since TNF- $\alpha$ plays a pathological role in the development of rheumatoid arthritis (RA), patients with severe RA are treated with anti-TNF- $\alpha$ therapy [58]. Interestingly, it has been reported that anti-TNF- $\alpha$ therapy enhanced FoxP3 ${ }^{+}$regulatory $\mathrm{T}$ cells in patients with RA via induction of TGF- $\beta$ [59]. Thus, these data suggest that TGF- $\beta$ protects bone from TNF- $\alpha$ induced bone damage by suppressing effecter $\mathrm{T}$ cell function and/or promoting induction of regulatory $\mathrm{T}$ cells. Besides TNF$\alpha$ IL-6, IL-17, and IL-23 can induce osteoclast differentiation resulting in bone resorption [60]. For instance, it has been reported that IL-17 promotes osteoclastgenesis via RANKL induction on osteoblasts [61]. Low levels of TGF- $\beta$ synergize with IL- 6 to induce Th17 differentiation, whereas high levels of TGF- $\beta$ result in development of Foxp $^{+}$regulatory $\mathrm{T}$ cells [62]. Furthermore, IL-17 and TNF- $\alpha$ have been shown to induce IL-6 and IL-23 expression in synovial fibroblast [63]. These findings could suggest that TGF- $\beta$ regulates osteoclast genesis by controlling Th17 differentiation.

RA is a disease mediated by both Th1 and Th17 cells, as both cell types accumulate in the joints of CIA mice [64]. In general, TGF- $\beta$ inhibits Th1 cells differentiation, however, recent findings indicated that RA is not a Th1mediated disease. For example, IFN- $\gamma$ (Th1 related cytokine) was hardly detected in the synovial fluids of RA patients [65]. Moreover, IFN- $\gamma$ has been shown to inhibit osteoclasts genesis in human [66]. Thus, the role of Th1 and Th17 cells in RA is still an open question.

\section{TGF- $\beta 1$ and regulatory T cells in osteogenesis}

Tregs induce and maintain immune tolerance, however several groups recently reported that regulatory $\mathrm{T}$ cells also promote bone formation. We have recently shown that $\mathrm{CD}^{+}{ }^{+}$Foxp3 ${ }^{+}$Tregs improved MSCs-mediated bone formation [67] by suppressing the number of infiltrating 
neutrophils in recipients, and the levels of IFN- $\gamma$, IL-6, and TNF- $\alpha$ in the MSCs implants. However, IL-4 and IL-10 levels were not affected. These findings suggest that Tregs-mediated anti-inflammatory milieu could promote favorable conditions for bone regeneration. Zaiss et al. reported that Foxp3-Tg mice that overexpress Foxp3 had higher bone mass and were protected from ovariectomy-induced bone loss [68]. The increase in bone mass resulted from impaired osteoclasts differentiation and bone resorption in vivo, not from upregulation of bone formation. Surprisingly, adoptive transfer of regulatory $\mathrm{T}$ cells into $\mathrm{RAG}-1^{-/-}$mice (mice who have no mature $\mathrm{T}$ and $\mathrm{B}$ cells in lymphoid organs) increased the bone mass, indicating that regulatory $\mathrm{T}$ cells could directly affect bone homeostasis without other $\mathrm{T}$ cell lineages engagement. Collectively, these findings provide evidence that regulatory $\mathrm{T}$ cells promoted bone formation.

\section{TGF- $\beta 1$ and Hormones}

TGF- $\beta 1$ interacts with soluble factors like hormones, such as estrogen, gluco-corticoids, parathyroid hormone (PTH), and vitamin D. Estrogen stimulates TGF- $\beta 1$ production in osteoblasts, and promotes osteoblasts proliferation and differentiation. Moreover, estrogen prevents bone loss by promoting osteoclasts apoptosis through a TGF- $\beta$ dependent mechanism [69]. Estrogen receptor $\alpha$ (ER- $\alpha)$ was identified as a co-repressor for Smad activity, and Smad3 was identified as an enhancer of ER- $\alpha$ mediated transcriptional activity, indicating that Estrogen and TGF- $\beta 1$ coordinate actions during bone formation [70].

Gluco-corticoids are known to promote apoptosis of osteoblasts and also inhibit their proliferation and differentiation while promoting the differentiation of osteoclasts [71]. Gluco-corticoids upregulate TGF- $\beta 1$ expression in osteoblasts, however, unlike estrogen, Gluco-corticoids synergise with TGF- $\beta$ enhanced osteoclast formation by stimulating the priming of osteoclast progenitors for differentiation into osteoclasts [72]. PTH, a polypeptide secreted by parathyroid glands, enhances bone formation by increasing TGF- $\beta$ mediated type I collagen production in osteoblasts. However, PTH concomitantly promotes bone resorption by binding to $\mathrm{PTH}$ receptor on osteoblasts and stimulating osteoblasts to increase their expression of RANKL but inhibits their expression of OPG [73]. Thus, PTH functions as a double-edged sword for bone metabolism.

Vitamin $\mathrm{D}$ is an important regulator of calcium homeostasis in bone. It stimulates bone formation by promoting osteoblast differentiation and extracellular matrix mineralization. Moreover, it inhibits PTHmediated bone resorption [74]. Vitamin D receptor (VDR) is expressed on osteoblast precursors, and vitamin $\mathrm{D}$ signals via VDR result in up-regulation of a bone formation gene, osteocalcin [75]. Osteocalcin released by osteoblast precursors induces maturation of osteoblasts [76]. The effect of TGF- $\beta 1$ on vitamin D functioning seems to diverge at the Smad3/MAPK level. Smad3 has been shown to act as a coactivator of vitamin D signaling to activate osteocalcin expression in a study using fibroblasts [77]. Interestingly, Smad3 binding elements and vitamin $\mathrm{D}$ responsive elements are closely located in the osteocalcin promoter [77]. On the other hand, TGF- $\beta 1$ mediated AP-1/MAPK signaling pathways seem to antagonize osteocalcin synthesis in an osteosarcoma cell line [78]. In conflicting reports using mouse osteoblasts, TGF- $\beta 1$ and vitamin D have been shown to both synergize and antagonize each other in bone formation $[79,80]$. Thus, it appears that signals transmitted through Smad3 and MAPK pathways evoke opposite effects on vitamin $\mathrm{D}$ functioning.

\section{Competing interests}

The authors declare that they have no competing interest.

\section{Authors' contributions}

SK drafted and WJC edited the manuscript. Both authors have read and approved the final manuscript.

\section{Acknowledgement}

We thank Dr. Eric Tu, and Dr. Joanne Konkel for their comments on the manuscript.

This research was supported by the Intramural Research Program of the $\mathrm{NIH}$.

Received: 2 October 2012 Accepted: 26 November 2012

Published: 15 January 2013

\section{References}

1. Rho J, Takami M, Choi Y: Osteoimmunology: interactions of the immune and skeletal systems. Mol Cells 2004, 17(1):1-9.

2. McKarns SC, Schwartz RH: Distinct effects of TGF-beta 1 on CD4+ and CD8+ T cell survival, division, and IL-2 production: a role for $\mathrm{T}$ cell intrinsic Smad3. J Immunol 2005, 174(4):2071-2083.

3. Shull MM, Ormsby I, Kier AB, Pawlowski S, Diebold RJ, Yin M, Allen R, Sidman C, Proetzel G, Calvin D, et al: Targeted disruption of the mouse transforming growth factor-beta 1 gene results in multifocal inflammatory disease. Nature 1992, 359(6397):693-699.

4. Kulkarni AB, Huh CG, Becker D, Geiser A, Lyght M, Flanders KC, Roberts AB, Sporn MB, Ward JM, Karlsson S: Transforming growth factor beta 1 null mutation in mice causes excessive inflammatory response and early death. Proc Natl Acad Sci U S A 1993, 90(2):770-774.

5. Carreno BM, Collins M: The B7 family of ligands and its receptors: new pathways for costimulation and inhibition of immune responses. Annu Rev Immunol 2002, 20:29-53.

6. Chen W, Jin W, Hardegen N, Lei KJ, Li L, Marinos N, McGrady G, Wahl SM: Conversion of peripheral CD4+CD25- naive T cells to CD4+CD25+ regulatory $T$ cells by TGF-beta induction of transcription factor Foxp3. J Exp Med 2003, 198(12):1875-1886.

7. Bellone $\mathrm{G}$, Aste-Amezaga M, Trinchieri G, Rodeck U: Regulation of NK cell functions by TGF-beta 1. J Immunol 1995, 155(3):1066-1073.

8. Lee WC, Zhong C, Qian S, Wan Y, Gauldie J, Mi Z, Robbins PD, Thomson AW, Lu L: Phenotype, function, and in vivo migration and survival of allogeneic dendritic cell progenitors genetically engineered to express TGF-beta. Transplantation 1998, 66(12):1810-1817.

9. Wahl SM, McCartney-Francis N, Allen JB, Dougherty EB, Dougherty SF: Macrophage production of TGF-beta and regulation by TGF-beta. Ann N Y Acad Sci 1990, 593:188-196.

10. Broide DH, Wasserman SI, Alvaro-Gracia J, Zvaifler NJ, Firestein GS: Transforming growth factor-beta 1 selectively inhibits IL-3-dependent 
mast cell proliferation without affecting mast cell function or differentiation. J Immunol 1989, 143(5):1591-1597.

11. Hayashi S, Gimble JM, Henley A, Ellingsworth LR, Kincade PW: Differential effects of TGF-beta 1 on lymphohemopoiesis in long-term bone marrow cultures. Blood 1989, 74(5):1711-1717.

12. Lomri A, Marie PJ: Bone cell responsiveness to transforming growth factor beta, parathyroid hormone, and prostaglandin E2 in normal and postmenopausal osteoporotic women. J Bone Miner Res 1990, 5(11):1149-1155.

13. Janssens K, Gershoni-Baruch R, Guanabens N, Migone N, Ralston S, Bonduelle M, Lissens W, Van Maldergem L, Vanhoenacker F, Verbruggen L, et al: Mutations in the gene encoding the latency-associated peptide of TGF-beta 1 cause Camurati-Engelmann disease. Nat Genet 2000, 26(3):273-275.

14. Rosen DM, Stempien SA, Thompson AY, Seyedin SM: Transforming growth factor-beta modulates the expression of osteoblast and chondroblast phenotypes in vitro. J Cell Physiol 1988, 134(3):337-346.

15. Seyedin SM, Thomas TC, Thompson AY, Rosen DM, Piez KA: Purification and characterization of two cartilage-inducing factors from bovine demineralized bone. Proc Natl Acad Sci U S A 1985, 82(8):2267-2271.

16. Thompson NL, Flanders KC, Smith JM, Ellingsworth LR, Roberts AB, Sporn $\mathrm{MB}$ : Expression of transforming growth factor-beta 1 in specific cells and tissues of adult and neonatal mice. J Cell Biol 1989, 108(2):661-669.

17. Kassem M, Kveiborg M, Eriksen EF: Production and action of transforming growth factor-beta in human osteoblast cultures: dependence on cell differentiation and modulation by calcitriol. Eur J Clin Invest 2000, 30(5):429-437

18. Jilka RL, Weinstein RS, Bellido T, Parfitt AM, Manolagas SC: Osteoblast programmed cell death (apoptosis): modulation by growth factors and cytokines. J Bone Miner Res 1998, 13(5):793-802.

19. Lucas PA: Chemotactic response of osteoblast-like cells to transforming growth factor beta. Bone 1989, 10(6):459-463.

20. Maeda S, Dean DD, Gomez R, Schwartz Z, Boyan BD: The first stage of transforming growth factor beta 1 activation is release of the large latent complex from the extracellular matrix of growth plate chondrocytes by matrix vesicle stromelysin-1 (MMP-3). Calcif Tissue Int 2002, 70(1):54-65.

21. D'Ippolito G, Schiller PC, Ricordi C, Roos BA, Howard GA: Age-related osteogenic potential of mesenchymal stromal stem cells from human vertebral bone marrow. J Bone Miner Res 1999, 14(7):1115-1122.

22. Alliston T, Choy L, Ducy P, Karsenty G, Derynck R: TGF-beta-induced repression of CBFA1 by Smad3 decreases cbfa1 and osteocalcin expression and inhibits osteoblast differentiation. EMBO J 2001, 20(9):2254-2272.

23. Maeda S, Hayashi M, Komiya S, Imamura T, Miyazono K: Endogenous TGFbeta signaling suppresses maturation of osteoblastic mesenchymal cells. EMBO J 2004, 23(3):552-563.

24. Centrella M, Casinghino S, Kim J, Pham T, Rosen V, Wozney J, McCarthy TL: Independent changes in type I and type II receptors for transforming growth factor beta induced by bone morphogenetic protein 2 parallel expression of the osteoblast phenotype. Mol Cell Biol 1995, 15(6):3273-3281.

25. Canalis E, Economides AN, Gazzerro E: Bone morphogenetic proteins, their antagonists, and the skeleton. Endocr Rev 2003, 24(2):218-235.

26. Zhou S: TGF-beta regulates beta-catenin signaling and osteoblast differentiation in human mesenchymal stem cells. J Cell Biochem 2011, 112(6):1651-1660.

27. Spinella-Jaegle S, Roman-Roman S, Faucheu C, Dunn FW, Kawai S, Gallea S, Stiot V, Blanchet AM, Courtois B, Baron R, et al: Opposite effects of bone morphogenetic protein-2 and transforming growth factor-beta1 on osteoblast differentiation. Bone 2001, 29(4):323-330.

28. Komori T: Regulation of bone development and maintenance by Runx2. Frontiers in bioscience: a journal and virtual library 2008, 13:898-903.

29. Hattersley $G$, Chambers TJ: Effects of transforming growth factor beta 1 on the regulation of osteoclastic development and function. J Bone Miner Res 1991, 6(2):165-172.

30. Murakami T, Yamamoto M, Ono K, Nishikawa M, Nagata N, Motoyoshi K, Akatsu T: Transforming growth factor-beta1 increases mRNA levels of osteoclastogenesis inhibitory factor in osteoblastic/stromal cells and inhibits the survival of murine osteoclast-like cells. Biochem Biophys Res Commun 1998, 252(3):747-752.

31. Pilkington MF, Sims SM, Dixon SJ: Transforming growth factor-beta induces osteoclast ruffling and chemotaxis: potential role in osteoclast recruitment. J Bone Miner Res 2001, 16(7):1237-1247.
32. Karst M, Gorny G, Galvin RJ, Oursler MJ: Roles of stromal cell RANKL, OPG, and M-CSF expression in biphasic TGF-beta regulation of osteoclast differentiation. J Cell Physiol 2004, 200(1):99-106.

33. Dieudonne SC, Foo P, van Zoelen EJ, Burger EH: Inhibiting and stimulating effects of TGF-beta 1 on osteoclastic bone resorption in fetal mouse bone organ cultures. J Bone Miner Res 1991, 6(5):479-487.

34. Takai H, Kanematsu M, Yano K, Tsuda E, Higashio K, Ikeda K, Watanabe K, Yamada $Y$ : Transforming growth factor-beta stimulates the production of osteoprotegerin/osteoclastogenesis inhibitory factor by bone marrow stromal cells. J Biol Chem 1998, 273(42):27091-27096.

35. Simonet WS, Lacey DL, Dunstan CR, Kelley M, Chang MS, Luthy R, Nguyen $H Q$, Wooden S, Bennett L, Boone T, et al: Osteoprotegerin: a novel secreted protein involved in the regulation of bone density. Cell 1997 89(2):309-319.

36. Seshasayee D, Wang H, Lee WP, Gribling P, Ross J, Van Bruggen N, Carano $R$, Grewal IS: A novel in vivo role for osteoprotegerin ligand in activation of monocyte effector function and inflammatory response. J Biol Chem 2004, 279(29):30202-30209.

37. Theoleyre S, Wittrant Y, Tat SK, Fortun Y, Redini F, Heymann D: The molecular triad OPG/RANK/RANKL: involvement in the orchestration of pathophysiological bone remodeling. Cytokine Growth Factor Rev 2004, 15(6):457-475

38. D'Amelio P, Isaia G, Isaia GC: The osteoprotegerin/RANK/RANKL system: a bone key to vascular disease. J Endocrinol Invest 2009, 32(4 Suppl):6-9.

39. Pittenger MF, Mackay AM, Beck SC, Jaiswal RK, Douglas R, Mosca JD, Moorman MA, Simonetti DW, Craig S, Marshak DR: Multilineage potential of adult human mesenchymal stem cells. Science 1999, 284(5411):143-147.

40. Cashman JD, Eaves AC, Raines EW, Ross R, Eaves CJ: Mechanisms that regulate the cell cycle status of very primitive hematopoietic cells in long-term human marrow cultures. I. Stimulatory role of a variety of mesenchymal cell activators and inhibitory role of TGF-beta. Blood 1990, 75(1):96-101.

41. Jiang $Y$, Jahagirdar BN, Reinhardt RL, Schwartz RE, Keene CD, Ortiz-Gonzalez $X R$, Reyes M, Lenvik T, Lund T, Blackstad M, et al: Pluripotency of mesenchymal stem cells derived from adult marrow. Nature 2002, 418(6893):41-49.

42. Jorgensen C, Djouad F, Apparailly F, Noel D: Engineering mesenchymal stem cells for immunotherapy. Gene Ther 2003, 10(10):928-931.

43. Kang JW, Kang KS, Koo HC, Park JR, Choi EW, Park YH: Soluble factorsmediated immunomodulatory effects of canine adipose tissue-derived mesenchymal stem cells. Stem Cells Dev 2008, 17(4):681-693.

44. Di Nicola M, Carlo-Stella C, Magni M, Milanesi M, Longoni PD, Matteucci P, Grisanti S, Gianni AM: Human bone marrow stromal cells suppress Tlymphocyte proliferation induced by cellular or nonspecific mitogenic stimuli. Blood 2002, 99(10):3838-3843.

45. Munn DH, Shafizadeh E, Attwood JT, Bondarev I, Pashine A, Mellor AL: Inhibition of T cell proliferation by macrophage tryptophan catabolism. $J$ Exp Med 1999, 189(9):1363-1372.

46. Chen W: IDO: more than an enzyme. Nat Immunol 2011, 12(9):809-811.

47. Rappaport RS, Dodge GR: Prostaglandin E inhibits the production of human interleukin 2. J Exp Med 1982, 155(3):943-948.

48. Park MJ, Park HS, Cho ML, Oh HJ, Cho YG, Min SY, Chung BH, Lee JW, Kim HY, Cho SG: Transforming growth factor beta-transduced mesenchymal stem cells ameliorate experimental autoimmune arthritis through reciprocal regulation of Treg/Th17 cells and osteoclastogenesis. Arthritis Rheum 2011, 63(6):1668-1680.

49. Massa G, Wyllie JP, Pratt AM, Molineux G, Schofield R: Marrow repopulation in mice treated with busulphan or isopropyl methane sulphonate and bone marrow. Br J Haematol 1987, 66(1):11-14.

50. Le Blanc K, Mougiakakos D: Multipotent mesenchymal stromal cells and the innate immune system. Nat Rev Immunol 2012, 12(5):383-396.

51. Wilson A, Trumpp A: Bone-marrow haematopoietic-stem-cell niches. Nat Rev Immunol 2006, 6(2):93-106.

52. Yamazaki S, Ema H, Karlsson G, Yamaguchi T, Miyoshi H, Shioda S, Taketo MM, Karlsson S, Iwama A, Nakauchi H: Nonmyelinating Schwann cells maintain hematopoietic stem cell hibernation in the bone marrow niche. Cell 2011, 147(5):1146-1158.

53. Gao Y, Qian WP, Dark K, Toraldo G, Lin AS, Guldberg RE, Flavell RA, Weitzmann MN, Pacifici R: Estrogen prevents bone loss through transforming growth factor beta signaling in T cells. Proc Natl Acad Sci U S A 2004, 101(47):16618-16623. 
54. Joyce ME, Roberts AB, Sporn MB, Bolander ME: Transforming growth factor-beta and the initiation of chondrogenesis and osteogenesis in the rat femur. J Cell Biol 1990, 110(6):2195-2207

55. Hill PA, Tumber A, Meikle MC: Multiple extracellular signals promote osteoblast survival and apoptosis. Endocrinology 1997, 138(9):3849-3858.

56. Kobayashi K, Takahashi N, Jimi E, Udagawa N, Takami M, Kotake S, Nakagawa N, Kinosaki M, Yamaguchi K, Shima N, et al: Tumor necrosis factor alpha stimulates osteoclast differentiation by a mechanism independent of the ODF/RANKL-RANK interaction. J Exp Med 2000, 191(2):275-286.

57. Chua CC, Chua BH, Chen Z, Landy C, Hamdy RC: TGF-beta1 inhibits multiple caspases induced by TNF-alpha in murine osteoblastic MC3T3E1 cells. Biochim Biophys Acta 2002, 1593(1):1-8.

58. Oldfield V, Plosker GL: Golimumab: in the treatment of rheumatoid arthritis, psoriatic arthritis, and ankylosing spondylitis. BioDrugs: clinical immunotherapeutics, biopharmaceuticals and gene therapy 2009, 23(2):125-135.

59. Nadkarni S, Mauri C, Ehrenstein MR: Anti-TNF-alpha therapy induces a distinct regulatory $T$ cell population in patients with rheumatoid arthritis via TGF-beta. J Exp Med 2007, 204(1):33-39.

60. Steiner G, Tohidast-Akrad M, Witzmann G, Vesely M, Studnicka-Benke A, Gal A, Kunaver M, Zenz P, Smolen JS: Cytokine production by synovial T cells in rheumatoid arthritis. Rheumatology (Oxford) 1999, 38(3):202-213.

61. Kotake S, Udagawa N, Takahashi N, Matsuzaki K, Itoh K, Ishiyama S, Saito S, Inoue K, Kamatani N, Gillespie MT, et al: IL-17 in synovial fluids from patients with rheumatoid arthritis is a potent stimulator of osteoclastogenesis. J Clin Invest 1999, 103(9):1345-1352.

62. Zhou L, Lopes JE, Chong MM, Ivanov II, Min R, Victora GD, Shen Y, Du J, Rubtsov YP, Rudensky AY, et al: TGF-beta-induced Foxp3 inhibits T(H)17 cell differentiation by antagonizing RORgammat function. Nature 2008, 453(7192):236-240.

63. Goldberg M, Nadiv O, Luknar-Gabor N, Agar G, Beer Y, Katz Y: Synergism between tumor necrosis factor alpha and interleukin-17 to induce IL-23 p19 expression in fibroblast-like synoviocytes. Mol Immunol 2009, 46(8-9):1854-1859.

64. Notley CA, Inglis JJ, Alzabin S, McCann FE, McNamee KE, Williams RO: Blockade of tumor necrosis factor in collagen-induced arthritis reveals a novel immunoregulatory pathway for Th1 and Th17 cells. J Exp Med 2008, 205(11):2491-2497.

65. Husby G, Williams RC Jr: Immunohistochemical studies of interleukin-2 and gamma-interferon in rheumatoid arthritis. Arthritis Rheum 1985, 28(2):174-181.

66. Takayanagi H, Ogasawara K, Hida S, Chiba T, Murata S, Sato K, Takaoka A, Yokochi T, Oda H, Tanaka $K$, et al: T-cell-mediated regulation of osteoclastogenesis by signalling cross-talk between RANKL and IFNgamma. Nature 2000, 408(6812):600-605.

67. Liu Y, Wang L, Kikuiri T, Akiyama K, Chen C, Xu X, Yang R, Chen W, Wang S, Shi S: Mesenchymal stem cell-based tissue regeneration is governed by recipient T lymphocytes via IFN-gamma and TNF-alpha. Nat Med 2011, 17(12):1594-1601.

68. Zaiss MM, Sarter K, Hess A, Engelke K, Bohm C, Nimmerjahn F, Voll R, Schett $G$, David JP: Increased bone density and resistance to ovariectomyinduced bone loss in FoxP3-transgenic mice based on impaired osteoclast differentiation. Arthritis Rheum 2010, 62(8):2328-2338.

69. Hughes DE, Dai A, Tiffee JC, Li HH, Mundy GR, Boyce BF: Estrogen promotes apoptosis of murine osteoclasts mediated by TGF-beta. Nat Med 1996, 2(10):1132-1136.

70. Matsuda T, Yamamoto T, Muraguchi A, Saatcioglu F: Cross-talk between transforming growth factor-beta and estrogen receptor signaling through Smad3. J Biol Chem 2001, 276(46):42908-42914.

71. Ash P, Loutit JF, Townsend KM: Osteoclasts derived from haematopoietic stem cells. Nature 1980, 283(5748):669-670.

72. Centrella M, McCarthy TL, Canalis E: Glucocorticoid regulation of transforming growth factor beta 1 activity and binding in osteoblastenriched cultures from fetal rat bone. Mol Cell Biol 1991, 11(9):4490-4496.

73. Qin L, Raggatt LJ, Partridge NC: Parathyroid hormone: a double-edged sword for bone metabolism. Trends Endocrinol Metab 2004, 15(2):60-65.

74. Keen RW, Spector TD: Role and evolution of therapeutic options. Osteoporos Int 1996, 6(Suppl 2):16-20.

75. Skjodt H, Gallagher JA, Beresford JN, Couch M, Poser JW, Russell RG: Vitamin D metabolites regulate osteocalcin synthesis and proliferation of human bone cells in vitro. J Endocrinol 1985, 105(3):391-396.
76. Galli M, Caniggia M: Osteocalcin. Minerva Med 1984, 75(42):2489-2501.

77. Subramaniam N, Leong GM, Cock TA, Flanagan JL, Fong C, Eisman JA Kouzmenko AP: Cross-talk between 1,25-dihydroxyvitamin D3 and transforming growth factor-beta signaling requires binding of VDR and Smad3 proteins to their cognate DNA recognition elements. J Biol Chem 2001, 276(19):15741-15746.

78. Banerjee C, Stein JL, Van Wijnen AJ, Frenkel B, Lian JB, Stein GS: Transforming growth factor-beta 1 responsiveness of the rat osteocalcin gene is mediated by an activator protein-1 binding site. Endocrinology 1996, 137(5):1991-2000.

79. Gurlek A, Kumar R: Regulation of osteoblast growth by interactions between transforming growth factor-beta and 1alpha,25dihydroxyvitamin D3. Crit Rev Eukaryot Gene Expr 2001, 11(4):299-317.

80. Staal A, Geertsma-Kleinekoort WM, Van Den Bemd GJ, Buurman CJ, Birkenhager JC, Pols HA, Van Leeuwen JP: Regulation of osteocalcin production and bone resorption by 1,25-dihydroxyvitamin D3 in mouse long bones: interaction with the bone-derived growth factors TGF-beta and IGF-I. J Bone Miner Res 1998, 13(1):36-43.

doi:10.1186/2045-3701-3-4

Cite this article as: Kasagi and Chen: TGF-beta1 on osteoimmunology and the bone component cells. Cell \& Bioscience 2013 3:4.

\section{Submit your next manuscript to BioMed Central and take full advantage of:}

- Convenient online submission

- Thorough peer review

- No space constraints or color figure charges

- Immediate publication on acceptance

- Inclusion in PubMed, CAS, Scopus and Google Scholar

- Research which is freely available for redistribution

Submit your manuscript at www.biomedcentral.com/submit
C) Biomed Central 